15. Odlin T. Language Transfer: Cross-Linguistic Influence in Language Learning. Cambridge, Cambridge University Press, 1989. 210 p.

16. Swan M. Learner English: A teachers guide to interference and other problems / [edited by] Michael Swan and Bernard Smith. 2nd ed. Cambridge, Cambridge University Press, 2001. 362 p.

УАК 371.314

\title{
ОКСАНА СЕРНЯК
}

oks_sern@.ukr.net кандидат педагогічних наук, доцент, Тернопільський національний педагогічний університет імені В. Гнатюка м. Тернопіль, вул. М. Кривоноса, 2

\section{ФОРМУВАННЯ ГОТОВНОСТІ СТУАЕНТІВ ФАКУАЬТЕТУ ІНОЗЕМНИХ МОВ АО ПРОХОАЖЕННЯ ПЕААГОГІЧНОЇ ПРАКТИКИ У ШКОАІ}

Досліджено формування готовності студентів факультету іноземних мов до проходження педагогічної практики у школі. Проаналізовано науково-методичні джерела щуодо готовності студентів факультету іноземних мов до проходження педагогічної практики у школі, яка $\epsilon$ важливою складовою у структурі підготовки майбутнього вчителя до професійної діяльності. Доведено, щзо підготовка вчителя іноземної мови передбачає усвідомлення майбутнім фахівцем своєї майбутної професійної діяльності як управління прочесом вивчення іноземної мови його учнями. Продемонстровано особливості формування готовності студентів факультету іноземних мов до проходження педагогічної практики у школі. Обгрунтовано методичні засади формування означеної якості в майбутніх вчителів іноземної мови, які передбачають професійну компетентність майбутнього вчителя, його ставлення до педагогічної діяльності, знання предмета, навички $i$ вміння їх практичного втілення, а також наявність комунікативної $i$ дидактичної потреби спілкування та передачі досвіду іншим. Визначено складові готовності студентів факультету іноземних мов до проходження педагогічної практики у школі. Розроблено та апробовано на практиці критерії оцінювання уроку англійської мови під час проходження педагогічної практики студентами факультету іноземних мов.

Ключові слова: педагогічна практика, управління навчально-пізнавальною діяльністю учнів, готовність до здійснення педагогічної діяльності, критерії оцінювання уроку англійської мови.

ОКСАНА СЕРНЯК

кандидат педагогических наук, доцент, Тернопольский национальный педагогический университет имени В. Гнатюка г. Тернополь, ул. М. Кривоноса, 2

\section{ФОРМИРОВАНИЕ ГОТОВНОСТИ СТУАЕНТОВ ФАКУАЬТЕТА ИНОСТРАННЫХ ЯЗЫКОВ К ПРОХОЖАЕНИЮ ПЕААГОГИЧЕСКОЙ ПРАКТИКИ В ШКОАЕ}

Исследовано формирование готовности студентов факультета иностранных языков $к$ прохождению педагогической практики в иколе.Осуществлен теоретический анализ научнометодической литературы по вопросам готовности студентов факультета иностранных языков $\kappa$ прохождению педагогической практики в школе, которая является важной составляющей в структуре подготовки будущего учителя к профессиональной деятельности. Доведено, что подготовка учителя иностранного языка предполагает осознание будущчи специалистом своей профессиональной деятельности как управление процессом изучения иностранного языка учениками.Исследовань особенности формирования готовности студентов факультета иностранных языков к прохождению педагогической практики в школе. Обосновань методические основы формирования указанного качества у будущих учителей иностранного языка, которые предусматривают профессиональную компетентность будущего учителя, его отночение к педагогической деятельности, знание предмета, навыки и умения их практического воплощзения, а также наличие коммуникативной и дидактической потребности общения и передачи опыта другим. Определены составляющчие готовности студентов факультета иностранных языков $к$ прохождению педагогической практики в иколе.Разработаны и 
апробированы на практике критерии оченки урока английского языка во время прохождения педагогической практики студентами факультета иностранных языков.

Ключевые слова: педагогическая практика, управление учебно-познавательной деятельностью учащихся, готовность к осуществлению педагогической деятельности, критерии оценки урока английского языка.

OKSANA SERNIAK

Candidate of Pedagogical Sciences, Associate Professor, Volodymyr Hnatiuk Ternopil National Pedagogical University Ternopil, Kryvonosa 2 Street

\section{THE FORMATION OF THE READINESS OF THE STUDENTS OF THE FACULTY OF FOREIGN LANGUAGES FOR THE TEACING PRACTICE AT SCHOOL}

The article investigates the formation of the readiness of students of the Faculty of Foreign Languages for the teaching practice at school. A theoretical analysis of scientific and methodological literature on the readiness of students of the Faculty of Foreign Languages for teaching practice at school is carried out. Teaching Practice is an important component in the structure of the training of the teachers to be for the professional activity. The preparation of a foreign language teacher implies his awareness of the future professional activities as management of the process of learning a foreign language by his students. There have been studied the peculiarities of forming the readiness of the students of the Faculty of Foreign Languages for the training practice at school, as well as the methodical principles of the formation of the specified quality in the foreign language teachers which include the professional competence of the teacher to be, his attitude to teaching, knowledge of the subject, skills and abilities of their practical appliance together with the ability of the specialist to carry out the communicative and didactic communication along with the ability to communicate his own knowledge and experience to others. There have been grounded the components of the readiness of students of the Faculty of Foreign Languages for teaching practice at school. There have been developed and tested in practice the criteria for assessing the English language lesson during the training practice.

Keywords: teaching practice, management of educational and cognitive activity of students, readiness for carrying out the pedagogical activity, criteria of assessment of the English language lesson.

Оновлення і реформування сфери освіти передбачає підвищення вимог до рівня підготовки педагогічних фахівців. Одним із центральних завдань, які постають перед сучасною вищою педагогічною школою, є формування високого рівня професійної компетентності майбутнього вчителя.

Ключовим етапом становлення професійної компетентності майбутнього вчителя $\epsilon$ педагогічна практика у школі. Саме педагогічна практика $є$ тим важливим етапом фахової підготовки майбутнього вчителя, у процесі якого відбувається інтеграція його знань, умінь та навичок, здобутих у педагогічному закладі. Педпрактика передбачає формування першого досвіду педагогічної професійної діяльності, а саме перенесення знань, умінь та навичок із педагогіки та методики викладання іноземної мови у сферу педагогічної праці, а також застосування означених знань, умінь та навичок у професійній діяльності з учнівським колективом.

Аналіз вітчизняних досліджень свідчить про значний рівень уваги до проблеми підготовки майбутніх педагогів до проходження педагогічної практики, котрій присвячено дослідження цілої низки науковців-дослідників і педагогів-практиків (С. Ю. Ніколаєва, О. В. Перетятко, Л. В. Пшенична. А. А. Сбруєва, М. І. Соловей, С. С. Спіцин, В. В. Черниш) [2; 4; 5].

Водночас, як свідчить практика роботи з студентами педагогічних ВНЗ, більшість 3 них зазнають чималих труднощів під час проходження першої педагогічної практики, яку майбутні вчителі проходять на четвертому році навчання у педагогічному ВНЗ.

Метою статті $\epsilon$ аналіз специфіки педагогічної практики як ключового етапу в процесі формування професійної компетентності майбутнього вчителя та висвітлення практичного досвіду організації педагогічної практики на факультеті іноземних мов.

Будучи однією із обовязкових навчальних дисциплін у педагогічному ВНЗ, педагогічна практика спрямована на набуття майбутніми вчителями комплексу умінь та навичок, необхідних для здійснення всіх видів навчально-виховної роботи в школі. Специфіка педагогічної практики 
полягає в тому, що вона є складним, багатоаспектним та багатофункціональним явищем, котрий вимагає спеціального підходу.

Під час педпрактики відбувається закріплення і поглиблення знань студентів 3 психологопедагогічних дисциплін, їх методичної підготовки та знань 3 предметів кваліфікаційнопрофесійного спрямування. Водночас педпрактика передбачає оволодіння майбутніми педагогами технологіями, формами та прийомами організації навчально-виховної роботи в школі, застосування педагогічних знань, умінь та навичок для вирішення визначених педагогічних завдань 3 конкретним учнівським колективом.

Головною метою педагогічної практики на факультеті іноземних мов є розвиток у майбутніх вчителів іноземної мови умінь застосовувати знання 3 педагогіки, психології та методики викладання іноземної мови у процесі проведення комунікативно-спрямованих уроків 3 використанням сучасних методів та прийомів активізації іншомовної діяльності учнів, а також здійснення виховної роботи засобами іноземної мови. Проходження педгогічної практики студентами факультету іноземних мов передбачає формування у них першого досвіду педагогічної професійної діяльності у процесі самостійного керівництва студентом-практикантом навчальновиховною роботою колективу учнів вивчення під час іноземної мови.

Проте, здійснене нами опитування студентів факультету іноземних мов ТНПУ імені Володимира Гнатюка доводить, що велика кількість студентів відчуває певну невпевненість перед цим, поза сумнівом, відповідальним етапом свого професійного становлення, відзначаючи низький рівень особистісної готовності до педагогічної діяльності, незважаючи на те, що більшість 3 них стверджує про наявність сформованості у них високого рівня знань 3 психолого-педагогічних дисциплін, методичної підготовки і спеціальних предметних знань професійного спрямування.

Так, тест на виявлення рівня теоретичної підготовки щодо змісту та особливостей педагогічного управління навчальними процесами виявив недостатній рівень означеного аспекту професійної підготовки студентів. Водночас, тест на визначення самоцінки управлінсько-педагогічних умінь продемонтстрував низький рівень означених умінь студентів. Разом 3 тим, діагностика мотиваційної налаштованості студентів на застосування новітніх форм та прийомів управління навчально-пізнавальною діяльністю учнів на уроці іноземної мови довела необхідність підвищення рівня означеної характеристики у методичному портфоліо майбутніх вчителів іноземної мови.

Це спонукає звернути особливу увагу на здійснення цілеспрямованої професійнопедагогічної підготовки студентів 3 метою забезпечення їхньої готовності до педагогічної діяльності у школі, понад усе з метою їх усвідомлення себе майбутніми вчителями, керівниками навчально-пізнавальної діяльності учнів.

Означений практичний підхід вимагає попереднього здійснення теоретичного аналізу науково-методичної літератури з питань готовності до професійної педагогічної діяльності.

Ю. В. Пелех тлумачить термін «професійна готовність» як інтегровану якість особистості, спрямовану на вирішення різнопланових професійних завдань за допомогою активізації i застосування цілісної системи набутих компетенцій [3, с. 37].

На переконання І. П. Підласого, готовність учителя до педагогічної діяльності є головною характеристикою педагога, яка передбачає сукупність обєднаних у систему природних і набутих якостей фахівця, які визначають здатність педагога виконувати професійні обовязки на належному рівні. Компонентами готовності до педагогічної діяльності є професійна самосвідомість вчителя, його ставлення та мотивація до педагогічної діяльності, знання предмета, навички і вміння їхнього практичного застосування, а також професійно значущі якості особистості вчителя [6, с. 54].

Аналіз психолого-педагогічних джерел 3 проблеми дозволяє нам трактувати готовність майбутніх учителів до педагогічної діяльності як сукупність соціально значущих особистісних якостей вчителя, які продуктивно реалізовуються у педагогічній практиці фахівця під час керівництва навчально-пізнавальною діяльністю учнів. Однією із найважливіших особистісних складових готовності до педагогічної діяльності вважаємо його здатність обирати оптимальні засоби педагогічного впливу на учнівський колектив, а також наявність у майбутнього фахівця комунікативної і дидактичної потреби спілкування та передачі досвіду іншим [7, с. 24].

Зміст вищезгаданих наукових положень 3 досліджуваної проблеми дає підставу для висновку, що рівень професійної готовності вчителя визначає рівень його успішного функціонування у майбутній професійній діяльності. 
Водночас сучасна вітчизняна педагогіка розглядає професійну діяльність вчителя як забезпечення ним стабільного функціонування і розвитку організованої навчально-пізнавальної діяльності учнів та досягнення оптимального результату в підготовці й належному вихованні учнів. Інакше кажучи основою фахової діяльності вчителя $\epsilon$ педагогічне управління навчальнопізнавальною діяльністю учнів [9, с. 32].

К. В. Астахова тлумачить управління педагогічним процесом як складний багатофакторний цілоеспрпямований процес впливу на керований обєкт, яким є учнівський колектив, за допомогою дії відповідних педагогічних технологій, методичних прийомів і засобів навчання, а також взаємодії впорядкованих систем, спрямованих на керування навчально-пізнавальною діяльністю учнів та досягнення на цій основі освітньо-виховних цілей [1, с. 19].

Аналіз проблем педагогічного управління навчальними процесами та специфіки педагогічного управління навчально-пізнавальною діяльністю учнів під час вивчення іноземної мови демонструє, що необхідним компонентом змісту професійної підготовки сучасного вчителя іноземної мови у вищому навчальному закладі $\epsilon$ формування готовності майбутнього вчителя до педагогічного управління навчально-пізнавальною діяльністю учнів, яка $\epsilon$ однією 3 ознак професійної компетентності та педагогічної майстерності вчителя іноземної мови.

Сучасна методика навчання іноземних мов розглядає педагогічне управління процесом вивчення іноземної мови як багатофакторну організаторську діяльність учителя 3 метою керівництва процесом навчання іноземної мови 3 урахуванням особливостей іншомовного навчального матеріалу, особливостей учнів, а також наявності технічних та інших засобів на основі використання обєктивних законів пізнавального процесу. Відтак, вчитель як керівник навчальнопізнавальної діяльності учнів у класі, безпосередньо здійснює управління означеною діяльністю 3 метою забезпечення належного рівня ефективності навчально-виховного процесу, а також морально-психологічного стану школярів [7, с. 30].

Щодо готовності до педагогічного управління навчально-пізнавальною діяльністю на уроці іноземної мови, то означена якість розглядається вченими як оволодіння вчителем іноземної мови організаційним досвідом управління навчально-пізнавальною діяльністю учнів на досконалому рівні з повним усвідомленням вчителем іноземної мови себе як керівника навчально-пізнавальною діяльністю учнів.

Ця педагогічна категорія відображає педагогічне управління навчально-виховним процесом колективу учнів, рівень управлінської підготовки педагога, його стиль у педагогічному управлінні діяльністю учнів, характер його професійної поведінки у педагогічному спілкуванні з учнівським колективом, а також мотиваційну налаштованість на самовдосконалення у цьому процесі.

Беручи до уваги вищезгадане, вважаємо, що сучасна підготовка вчителя іноземної мови повинна спрямовуватися насамперед на те, щоб майбутній фахівець усвідомлював свою професійну діяльність як управління процесом вивчення іноземної мови його учнями.

Здійснений теоретичний аналіз науково-методичної літератури 3 питань педагогічного управління навчально-пізнавальною діяльністю учнів в процесі вивчення іноземної мови забезпечує теоретичне підгрунтя розуміння готовності студентів факультету іноземних мов до проходження педагогічної практики і водночас спонукає до здійснення пропедевтичних засобів та практичних дій 3 метою підвищення рівня готовності студентів до проходження педагогічної практики.

На наше переконання, вирішення цієї проблеми можливе за умови, коли формування готовності вчителя до педагогічного управління навчально-пізнавальною діяльністю учнів буде становити певну підсистему в загальній структурі професійних знань майбутнього вчителя іноземної мови. Майбутній вчитель іноземної мови має бути психологічно, знаннєво і технологічно готовим до здійснення організаторських та управлінських функцій у процесі навчання і виховання своїх учнів. Це - одна $з$ важливих складових його професійної підготовки до педагогічної діяльності.

Водночас готовність до педагогічного управління та постійне іiі вдосконалення виступає однією з ознак професійної компетентності та педагогічної майстерності вчителя іноземної мови. Від рівня цієї підготовки головним чином залежить ефективність управління майбутнім вчителем іноземної мови навчально-пізнавальною діяльністю учнів, а відтак і результати діяльності учнівського колективу, яким він буде керувати, що забезпечить можливість успішного досягнення педагогом поставлених навчальних цілей. 
3 цією метою на факультеті іноземних мов ТНПУ ім. В. Гнатюка педагогічній практиці передують певні пропедевтичні заходи, спрямовані на формування готовності студентів факультету іноземних мов до проходження педпрактики у школі. Одним з важливих пропедевтичних моментів $\epsilon$ доведення до відома до майбутніх практикантів та обговорення з ними розроблених методистами критеріїв оцінки готовності до педагогічної практики у школі.

Так, готовність майбутнього вчителя іноземної мови до проходження педагогічної практики у школі передбачає насамперед сформованість таких складових, як методична, мовленнєва, психолого-педагогічна підготовка студента-практиканта, а також його комунікативна поведінка на уроці та адекватність застосування засобів навчання. Детальний опис чинників кожного аспекта готовності до проходження педпрактики у школі, а також кількість балів для здійснення самооцінки студентом-практикантом свого рівня готовності представлені у табл. 1.

Таблиця 1

Критерії оіцнювання готовності студента-практиканта до проходження педпрактики

\begin{tabular}{|c|c|}
\hline $\begin{array}{l}0-10 \\
\text { балів }\end{array}$ & $\begin{array}{l}\text { Методична підготовка студента-практиканта } \\
\text { Вмотивоване використання різних видів роботи на уроці (фронтальної, колективної, } \\
\text { групової та індивідуальної роботи) на різних етапах уроку. } \\
\text { Раціональність вибору вправ на різних етапах уроку, їх методична характеристика, } \\
\text { взаємозв'язок і системність вправ, послідовність їх виконання. } \\
\text { Забезпечення студентом-практикантом комунікативного характеру вправляння на уроці: } \\
\text { наявність мовленнєвоїдіяльності у різних ситуаціях з певною метою. } \\
\text { Забезпечення студентом-практикантом умов для іншомовного спілкування учнів у процесі } \\
\text { виконання комунікативних вправ. }\end{array}$ \\
\hline $\begin{array}{c}0-10 \\
\text { балів }\end{array}$ & $\begin{array}{l}\text { Мовленнєва підготовка студента-практиканта } \\
\text { Рівень мовленнєвої підготовки студента-практиканта (високий, достатній, недостатній). } \\
\text { Культура мовлення (правильність, виразність, зверненість, емоційна забарвленість). } \\
\text { Чіткість, доступність формулювання студентом-практикантом завдань. } \\
\text { Раціональність висловлювання рідною мовою на уроці; Співвідношення мовлення вчителя } \\
\text { і учнів. }\end{array}$ \\
\hline $\begin{array}{l}0-10 \\
\text { балів }\end{array}$ & $\begin{array}{l}\text { Комунікативна поведінка студента-практиканта на уроці } \\
\text { Стиль проведення уроку (жвавий, млявий, захоплюючий, монотонний, такий, що спонукає } \\
\text { учнів до пасивного споглядання, такий, що спонукає учнів до активної участі у роботі, } 3 \\
\text { навязуванням вчителем тільки своєї точки зору, такий, де більшість часу займає діяльність } \\
\text { самого студента-практиканта). } \\
\text { Ставлення студента-практиканта до учнів (уважне, байдуже, вимогливе, суворе, дуже } \\
\text { суворе, поблажливе). } \\
\text { Контакт з учнями (добрий, достатній, недостатній, майже відсутній); } \\
\text { Рівень зворотного зв'язку у роботі з учнями. } \\
\text { Комунікативні здібності студента-практиканта (здатність до спілкування з дітьми, уміння } \\
\text { знайти правильний підхід до учнів, встановити з ними вмотивовані, з педагогічної точки } \\
\text { зору, стосунки). } \\
\text { Здатність студента-практиканта бути одночасно і партнером і учителем, який направляє } \\
\text { мовленнєве спілкування і коригує його недоліки (авторитарність, імперативність, } \\
\text { зацікавленість у спілкуванні з учнями). }\end{array}$ \\
\hline $\begin{array}{l}0-10 \\
\text { балів }\end{array}$ & $\begin{array}{l}\text { Психолого-педагогічна підготовка студента } \\
\text { Особистісна готовність до педагогічної діяльності (наявність комунікативної і дидактичної } \\
\text { потреби, потреби спілкування, передачі досвіду іншим). } \\
\text { Ставлення студента-практиканта до учнів (зацікавлене, нейтральне, байдуже, зверхнє, } \\
\text { запобігливе). } \\
\text { Рівень педагогічного такту. } \\
\text { Уміння підтримувати зацікавленість учнів впродовж усього уроку (достатнє, } \\
\text { середнє,недостатнє). } \\
\text { Уміння вчителя впливати на дотримання дисципліни учнями на уроці. Адекватність } \\
\text { реагування вчителя на порушення дисципліни. } \\
\text { Рівень ефективності роботи вчителя } 3 \text { метою виправлення допущених учнями помилок, їх } \\
\text { запобігання і усунення упроцесі навчально-пізнавальної діяльності в класі. }\end{array}$ \\
\hline
\end{tabular}




\begin{tabular}{|c|c|}
\hline & $\begin{array}{l}\text { ахування студентом-практикантом індивідуальних/ особистісних особливостей учнів. } \\
\text { ооційний стан вчителя на уроці (настрій, зібраність, уміння володіти собою, впевненість, } \\
\text { моконтроль). } \\
\text { явність елементів педагогічної творчості на уроці, нетрадиційних методів і прийомів). } \\
\text { льтура зовнішнього вигляду та поведінки студента-практиканта; }\end{array}$ \\
\hline $\begin{array}{c}0-5 \\
\text { балів }\end{array}$ & $\begin{array}{l}\text { Застосування засобів навчання } \\
\text { Використання дидактичного роздавального матеріалу на уроці, його відповідність } \\
\text { цілям навчання. } \\
\text { Використання технічних засобів навчання. Методична ефективність їх використання. } \\
\text { Використання дошки. Грамотність записів, ї відповідність каліграфічній нормі, } \\
\text { правильність розташування, доцільність записів, їх достатність. }\end{array}$ \\
\hline
\end{tabular}

Пропедевтичне обговорення 3 майбутніми практикантами критеріїв оцінювання уроку англійської мови, на наше переконання, сприяє підвищенню рівня усвідомленого та вдумливого підходу студентів-практикантів до підготовки до уроків з учнівським класом. В узагальненому вигляді вони представлені у табл. 2.

Таблиця 2

Критерії очінювання уроку аналійської мови

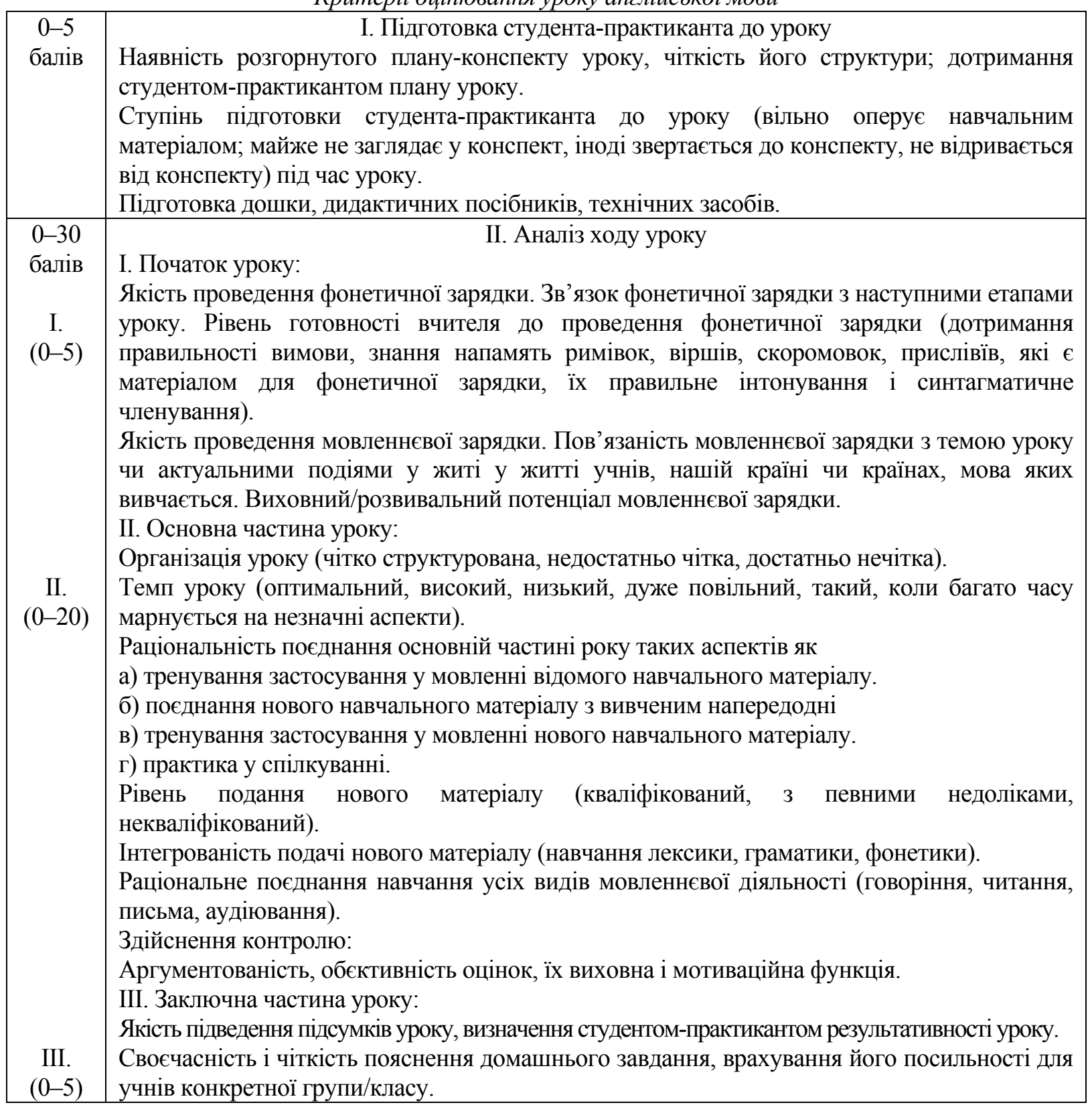


Проходження педпрактики студентами факультету іноземних мов передбачає і організацію позакласної роботи з учнями. Як вказує Г. І Сорока, мета позакласної роботи з іноземної мови має кілька аспектів, одним із найголовнішим 3 яких $€$ виховувати та підтримувати у школярів мотивацію до оволодіння іноземною мовою $[8$, с.48].

Водночас методисти виокремлюють такі чинники, як сприяння підвищенню рівня володіння учнями іноземною мовою; розширення знань учнів про соціально-економічні особливості та культуру країни, мова якої вивчається; формування лінгвокраїнознавчої компетенції школярів; формування лінгвокраїнознавчої компетенціїу чнів; розвиток творчих здібностей школярів [4, с. 67].

Основними вимогами організації позакласної роботи з іноземної мови $є$ тісний зв'язок 3 класною роботою 3 іноземної мови; організація колективної взаємодії учнів; створення невимушеної атмосфери під час підготовки та проведення позакласних виховних заходів. У позакласній роботі з іноземної мови студенти-практиканти повинні враховувати інтереси та здібності учнів. Позакласний захід з іноземної мови має бути емоційно насиченим і мати захоплюючий характер. Проведення заходу не передбачає чітко визначених домашніх завдань i чітко визначеної оцінки діяльності учнів.

Позакласна робота передбачає керівництво студентами-практикантами учнівською підготовкою повідомлень, доповідей, розучування віршів, пісень, уривків 3 літературних творів іноземною мовою, виготовлення наочних засобів, оформлення стіннівок, альбомів, стендів тощо.

Таким чином, підготовка миайбутнього вчителя іноземної мови, здатного забезпечити необхідний рівень навчання і виховання учнівського колективу, вимагає формування високого рівня готовності педагога до педагогічного управління навчально-пізнавальною діяльністю учнів безпосередньо у вищому навчальному закладі. Будучи найскладнішим етапом формування професійної компетентності майбутнього спеціаліста, педагогічна практика є ключовим моментом оволодіння майбутнім вчителем іноземної мови умінням застосувати свої знання, уміння і навички у процесі розвитку професійної педагогічної компетентності.

Водночас пропедевтична підготовка студентів факультету іноземних мов до проходження педпрактики у школі сприятиме усвідомленню студентами власної готовності до майбутньої професійної діяльності, дозволяючи майбутньому фахівцю визначити рівень своєї відповідності вимогам та специфіці педагогічної діяльності, а також намітити програму професійного самовдосконалення з метою здійснення професійної педагогічної діяльності на належному рівні.

\section{ЛІТЕРАТУРА}

1. Астахова К. В. Трансформація вищої освіти вимагає трансформації управління вищою школою / К. В. Астахова // Педагогіка і психологія. - 2002. - №3. - С. 19 - 22

2. Організація педагогічної практики в кредитно-модульній системі навчання (освітньокваліфікаційні рівні «бакалавр», «спеціаліст») / Укл.: Соловей М. І., Ніколаєва С. Ю., Спіцин Є. С. та ін. - К: Ленвіт, 2006. - 106 с.

3. Пелех Ю. В. Ціннісно-смисловий концепт професійної підготовки майбутнього педагога: монографія; за ред. М. Б. Свтуха / Ю. В. Пелех. - Рівне: Тетіс, 2009. - 400 с.

4. Педагогічна практика з методики викладання іноземних мов у середніх навчальних закладах / Кол. авторів під кер. С. Ю. Ніколаєвої і В. В. Черниш. - К.: Ленвіт, 2003. - 250 с.

5. Педагогічна практика: навч.-метод, посібник. У 2 ч. / За ред. Л. В. Пшеничної, А. А. Сбруєвої, О. В. Перетятко. - Суми: СДПУ, 2004. - 180 с.

6. Підласий І. П. Інтерактивний підручник для педагогів ринкової системи освіти / І. П. Підласий. К.: Видавничий Дім «Слово», 2004. - 616 с.

7. Серняк О. М. Теоретико-методичні основи педагогічного управління колективною навчальнопізнавальною діяльністю учнів. Методичні рекомендації до вивчення спецкурсу / О. М. Серняк. Тернопіль: ТНПУ, 2008. -60 c.

8. Сорока Г. І. Планування та аналіз виховної роботи школи / Г. І. Сорока. - Харків: Основа, 2003. - 63 с.

9. Товажнянський Л. Л. Педагогіка управління навч.посібник / Л. Л. Товажнянський, О. Г. Романовський, О.С. Пономарьов. - Харків: НТУ “ХПІ”, 2003. - 408 с.

\section{REFERENCES}

1. Astakhova K.V. Transformatsiya vyshchoyi osvity vymahaye transformatsiyi upravlinnya vyshchoyu shkoloyu [Transformation of higher education requires transformation of higher educational system] / K.V. Astakhova // Pedahohika i psykholohiya. - 2002. - № 3. - PP. 19-22.

2. Orhanizatsiya pedahohichnoyi praktyky $v$ kredytno-modulniy systemi navchannya (osvitno-kvalifikatsiyni rivni «bakalavr», "spetsialist») [Organization of teaching practice in the credit-module system of 
education (educational and qualification levels "Bachelor", "Specialist") / Ukl.: Solovey M.I., Nikolayeva S.YU., Spitsyn YE.S. ta in. - K.: Lenvit, 2006. - 106 p.

3. Pelekh Y.V. Tsinnisno-smyslovyy kontsept profesiynoyi pidhotovky maybutoho pedahoha: monohrafiya [Value and semantic concept of professional training of the future teacher] / YU. V. Pelekh; za redaktsijeju M. B. Yevtukha. - Rivne: Tetis, 2009. - 400 p.

4. Pedahohichna praktyka z metodyky vykladannya inozemnykh mov u serednikh navchalnykh zakladakh [Teaching Practice on the Methodology of Teaching Foreign Languages in Secondary schools] / Kol. avtoriv pid ker. S. YU. Nikolayevoyi i V. V. Chernyshch - K.:Lenvit, 2003. - 250 p.

5. Pedahohichna praktyka: navch.-metod, posib. [Teaching practice]-U $2 \mathrm{ch}$. Z Za red. L. V. Pshenychnoyi. A. A. Sbruyevoyi, O.V.Peretyatko. - Sumy: SDPU, 2004. -180 p.

6. Pidlasyy I.P. Interaktyvnyy pidruchnyk dlya pedahohiv rynkovoyi systemy osvity [Interactive tutorial for educators of the market education system] / I. P. Pidlasyy - K.: Vydavnychyj Dim «Slovo», 2004. - 616 p.

7. Sernyak O. M. Teoretyko-metodychni osnovy pedahohichnoho upravlinnya kolektyvnoyu navchal nopiznavalnoyu diyalnistyu uchniv. Metodychni rekomendatsiyi do vyvchennya spetskursu. [Theoretical and methodological foundations of pedagogical management of cooperative learning and cognitive activity of students ] / O. M. Sernyak. - Ternopil: TNPU, 2008. - 60 p.

8. Soroka H.I. Planuvannya ta analiz vykhovnoyi roboty shkoly [Planning and analysis of the educative work in schools]. - Kharkiv: Osnova, 2003. - 63 p.

9. Tovazhnyanskyj L. L., Romanovskyy O. H., Ponomarov O. S. Pedahohika upravlinnya [Pedagogical management]. - Kharkiv: NTU “KHPI”, 2003. - 408 p.

УАК 378:37.091.12.011.3 - 051: [811.111:37.091.33-028.17

ІРИНА БІАЯНСЬКА

iryna.bezruka@hotmail.co.uk аспірантка,

Тернопільський національний педагогічний університет імені В. Гнатюка

м. Тернопіль, вул. М. Кривоноса, 2

\section{ПСИХОАІНГВІСТИЧНІ ПЕРЕАУМОВИ ФОРМУВАННЯ ІНШОМОВНОЇ АУАИТИВНОЇ КОМПЕТЕНТНОСТІ МАЙБУТНІХ УЧИТЕАІВ ЗАСОБАМИ ХУАОЖНІХ АУАІОКНИГ}

Розкрито психолінгвістичні особливості аудіювання художніх аудіокниг та визначено передумови формування іншомовної аудитивної компетентності майбутніх учителів на їх основі, проаналізовано функиіонування психічних проиесів та психологічних механізмів аудіювання, а також механізмів художнього сприйняття. Виокремлено та проаналізовано такі механізмами аудіювання художніх аудіокниг: психічні процеси (сприйняття, мислення, память, увага), психологічні механізми (мовленнєвий слух, внутрішне промовляння, ймовірнісне прогнозування, осмислення, оперативна память), механізми художнього сприйняття (емоції та почуття, уява, апперцеепія, образне та асоціативне мислення), механізми смислової переробки інформації (механізм еквівалентних замін, перекодування, компресії, розиирення, трансформації). Обгрунтовано важливість механізмів обробки інформачії для осмислення художніх творів на слух та визначено відповідні уміння. Зроблено висновок, щуо для ефективного формування іншомовної аудитивної компетентності засобами аудіокниг необхідно: враховувати інтереси студентів, мотивувальні чинники та установки; розвивати уміння переробки інформації; тренувати роботу механізмів аудіювання; активувати апперцепџію перед прослуховуванням; створити умови, за яких студенти мають можливість поділитись своєю проекцією твору, створити «вторинний текст».

Ключові слова: аудитивна компетентність, аудіокниги, аудіювання, психолінгвістичні передумови, психологічні механізми, художнє сприйняття.

ИРИНА БИАЯНСКАЯ

аспирантка,

Тернопольский национальный педагогический университет имени В. Гнатюка

г. Тернополь, ул. М. Кривоноса, 2 